Original Research Paper

\title{
The Distribution of Molluscs Has Economic Value Concerning Substrate Characteristics in Lake Maninjau
}

\author{
Muhamad Suhaemi Syawal $^{1 *}$, Yusli Wardiatno ${ }^{2}$, Sigid Hariyadi \\ ${ }^{1}$ Research Center for Limnology, The Indonesian Institute of Sciences- LIPI, J1. Raya Bogor-Jakarta km 46, \\ Bogor 16911, Indonesia \\ ${ }^{2}$ Department of Aquatic Resources Management, Faculty of Fisheries and Marine Science, Bogor Agricultural University, \\ Kampus IPB Darmaga, Bogor 16680, Indonesia.
}

\author{
Article History \\ Received : November $30^{\text {th }}, 2020$ \\ Revised : December $10^{\text {th }}, 2020$ \\ Accepted : December $14^{\text {th }}, 2020$ \\ Published : December $18^{\text {th }}, 2020$ \\ *Corresponding Author: \\ Muhamad Suhaemi Syawal \\ Research Center for Limnology, \\ The Indonesian Institute of \\ Sciences- LIPI, Jl. Raya Bogor- \\ Jakarta km 46, \\ Bogor 16911, Indonesia; \\ Email: \\ syawal@limnologi.lipi.go.id
}

\begin{abstract}
Lake Maninjau is one of the tectovulcanic type lakes in West Sumatra Province which is used as a food source in the presence of fauna groups such as molluscs. The presence of molluscs in the lake is related to the substrate characteristics. The main purpose of this study is to determine the distribution of molluscs concerning the substrate in Lake Maninjau. The sampling of substrate and molluscs was conducted three times from MarchSeptember 2015 at seven observation stations on the coastal water of Lake Maninjau. The result of the study shows that Corbicula moltkiana was mostly found at Pandan station, while Melanoides tuberculata and Anodonta woodiana were mostly found at Muko-Muko station. The distribution pattern of Corbicula moltkiana and Melanoides tuberculata shows a tendency to live in groups. The coastal water of Lake Maninjau are dominated by sand with TN and TP concentrations ranged from $0.093-0.610 \mathrm{mg} \mathrm{kg}-1$ and 0.427 $2.137 \mathrm{mg} \mathrm{kg}-1$, respectively. Substrate characteristics that are dominated by sand on the coastal water of Lake Maninjau supports the presence of molluscs has economic value. Further studies can be directed at other species of the molluscs group that have economic potential.
\end{abstract}

Keywords: Molluscs, Substrate, Lake Maninjau

\section{Pendahuluan}

Danau Maninjau merupakan salah satu danau bertipe tektovulkanik di Indonesia yang memiliki berbagai fungsi yaitu sebagai pembangkit listrik tenaga air, pariwisata, sumber air irigasi serta kegiatan sektor perikanan. Sumber air D. Maninjau terutama berasal dari sungai-sungai yang mengalir sepanjang daerah aliran sungai (DAS) yang bermuara ke danau dan air hujan. Perairan danau umumnya akan menerima masukan air dari daerah tangkapan air di sekitar danau, sehingga cenderung menerima bahan-bahan terlarut yang terangkut bersamaan dengan air yang masuk. Oleh karena itu konsentrasi zat-zat yang terdapat di danau merupakan resultante dari zat-zat yang berasal dari aliran air yang masuk (Payne, 1986). Meningkatnya pencemaran yang masuk ke danau umumnya juga disebabkan oleh kebiasaan masyarakat di sekitar danau yang membuang limbah domestik, baik limbah cair maupun limbah padat langsung ke perairan danau (Hehanussa dan Haryani, 2009).

Pencemaran di perairan danau dapat mempengaruhi penurunan keanekaragaman hayati termasuk spesies endemik (Kumurur, 2002). Keberadaan biota danau seperti kerang dan ikan sudah semakin terancam akibat peningkatan pencemaran di badan air danau, sehingga menyebabkan kualitas ekosistem danau semakin menurun (Marganof, 2007). Moluska merupakan salah satu filum dari kelompok hewan avertebrata dengan anggota terbanyak kedua setelah filum Arthropoda (Brusca \& Brusca, 1990). Moluska memiliki sifat hidup yang relatif menetap sehingga rentan terhadap perubahan lingkungan (Arbi, 2016). Kehadirannya di perairan berkaitan pula dengan karakteristik sedimen. Karakteristik sedimen akan mempengaruhi morfologi, fungsional, tingkah laku, serta nutrien fauna moluska (Shalihah et al. 2017).

Bagian dari kelompok Moluska seperti pensi memiliki peran ekologis penting terkait perannya di dalam siklus bahan organik dan posisinya di dalam jaring makanan. Menurut Sousa et al. (2007) dalam Lukman (2015), satu spesies Corbicula yaitu $C$. fluminea selain sebagai penyaring makanan (filter feeder) juga sebagai pengaduk makanan (pedal 
feeder). Peran pertama adalah memanfaatkan sumber makanan dari kolom air dan peran kedua yaitu memanfaatkan sumber makanan dari sedimen. Secara umum kelompok bivalvia dapat memanfaatkan seston, bahan partikulat, yang memiliki kisaran ukuran dari 1 $\mu \mathrm{m}$ hingga 40-100 $\mu \mathrm{m}$, baik dari kelompok bakteri, nano fitoplankton, zooplankton kecil, dan berbagai jenis detritus (Manganaro et al. 2009).

Populasi moluska khususnya pensi (Corbicula moltkiana), langkitang (Melanoides tuberculata) dan lokan (Anodonta woodiana) sebagai bagian dari komunitas bentik sangat terancam dengan kondisi anoksik di wilayah dasar perairan. Di sisi lain, moluska seperti pensi dan langkitang merupakan sumber pangan bagi penduduk sekitar danau dan memiliki nilai ekonomi yang tinggi karena laku diperjualbelikan (Tanjung, 2015). Penelitian terkait ekologi moluska di perairan danau diantaranya telah dilaporkan oleh Marwoto \& Djajasasmita (1986), Surbakti (2011), Hamidah (2015), dan Mardatila et al. (2016), namun kajian moluska bernilai ekonomis dalam kaitannya dengan karakteristik substrat di danau belum banyak dilaporkan. Penelitian ini dilakukan untuk mengetahui distribusi moluska bernilai ekonomis dalam kaitannya dengan karakteristik substrat di perairan Danau Maninjau.

\section{Bahan dan Metode}

\section{Waktu dan Tempat}

Pengambilan sampel sedimen dan moluska dilakukan selama tiga kali dari bulan Maret-September 2015 di tujuh lokasi muara sungai-sungai di sekitar Danau Maninjau (Gambar 1).

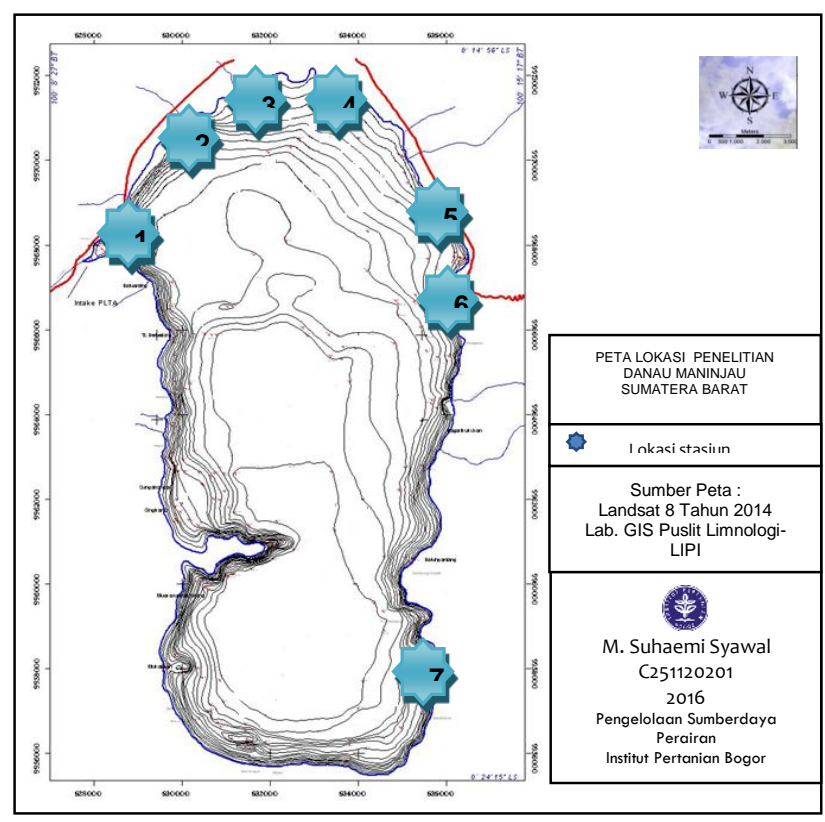

Gambar 1. Lokasi Penelitian di perairan Danau Maninjau
Sedimen permukaan diambil menggunakan Ekman grab sebanyak \pm 1500 gram berat basah dan dimasukan ke dalam kantong plastik untuk selanjutnya dikeringkan dalam oven $30^{\circ} \mathrm{C}$ hingga diperoleh berat kering. Sampel moluska diambil menggunakan Ekman grab dan dipisahkan dari sedimen yang selanjutnya diidentifikasi jenisnya dan disimpan di dalam wadah yang sudah diberi formalin 5\% atau alkohol $10 \%$. Analisis contoh dilakukan di Laboratorium Hidrokimia, Pusat Penelitian Limnologi-LIPI.

Tabel 1. Karakteristik Lokasi Penelitian di perairan Danau Maninjau

\begin{tabular}{|c|c|c|}
\hline $\begin{array}{l}\text { Kode } \\
\text { Lokasi }\end{array}$ & $\begin{array}{l}\text { Nama } \\
\text { lokasi }\end{array}$ & Keterangan \\
\hline St. 1 & $\begin{array}{l}\text { Muko- } \\
\text { Muko }\end{array}$ & $\begin{array}{l}\text { - } \text { Terdapat intake PLTA } \\
\text { - Outlet Danau Maninjau } \\
\text { - Kawasan wisata } \\
\text { - } \text { Banyak KJA }\end{array}$ \\
\hline St. 2 & $\begin{array}{l}\text { Talao } \\
\text { Tubo }\end{array}$ & $\begin{array}{l}\text { - Persawahan } \\
\text { - Banyak KJA } \\
\text { - Pemukiman padat penduduk }\end{array}$ \\
\hline St. 3 & $\begin{array}{l}\text { Muaro } \\
\text { Talao }\end{array}$ & $\begin{array}{l}\text { - Terdapat persawahan } \\
\text { - KJA sedikit }\end{array}$ \\
\hline St. 4 & $\begin{array}{l}\text { Muara } \\
\text { Tanjung }\end{array}$ & $\begin{array}{l}\text { - Persawahan/perkebunan } \\
\text { - Rumah pendukuk sedikit } \\
\text { - Banyak KJA }\end{array}$ \\
\hline St. 5 & Bayur & $\begin{array}{ll}\text { - } & \text { Pusat (KJA) } \\
\text { - } & \text { Pasar tradisional } \\
\text { - } & \text { Pemukiman padat penduduk } \\
\text { - } & \text { Hotel dan bengkel } \\
& \text { kendaraan }\end{array}$ \\
\hline St. 6 & $\begin{array}{l}\text { Muaro } \\
\text { Pisang }\end{array}$ & $\begin{array}{l}\text { - Pasar tradisIonal } \\
\text { - Pemukiman padat penduduk } \\
\text { - } \text { Banyak KJA }\end{array}$ \\
\hline St. 7 & Pandan & $\begin{array}{l}\text { - Terdapat pasar tradisIonal } \\
\text { - Pemukiman padat penduduk }\end{array}$ \\
\hline
\end{tabular}

\section{Hasil dan Pembahasan}

\section{Jumlah Moluska di Muara Sungai}

Jumlah moluska jenis pensi atau Corbicula moltkiana tertinggi terdapat di St. 7 (Pandan) dan terendah di St. 1 (Muko-muko) (Gambar 2). Namun untuk jenis langkitang atau Melanoides tuberculata tertinggi terdapat di St. 1 (Muko-muko) dan terendah di St. 2 (Talao tubo), sementara untuk jenis lokan atau Anodonta Woodiana tertinggi terdapat di St. 1 (Muko-muko) dan 
terendah di St. 7 (Pandan). Tinggi rendahnya kepadatan moluska dipengaruhi oleh kandungan bahan organik yang terdapat di sedimen yang bersumber dari sungai maupun dari badan danau itu sendiri. Komunitas moluska dipengaruhi oleh konsentrasi oksigen terlarut dan bahan organik sedimen (Zettler et al. 2009). Spesies yang dapat hidup pada suatu kondisi ekstrim akan menderita stress fisiologis (Sastrawijaya, 1991).
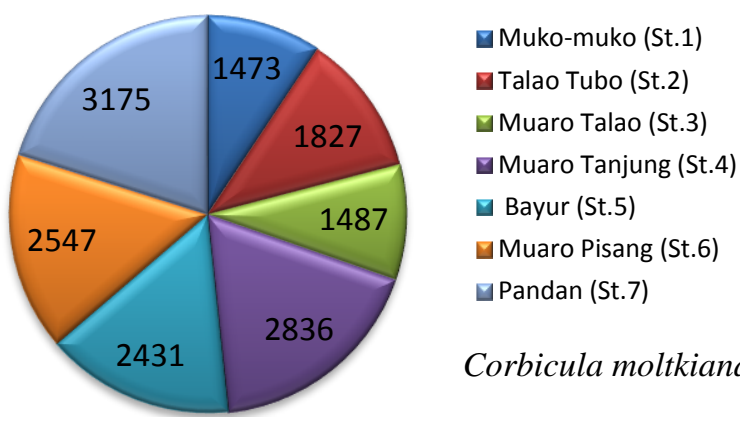

\section{Corbicula moltkiana}

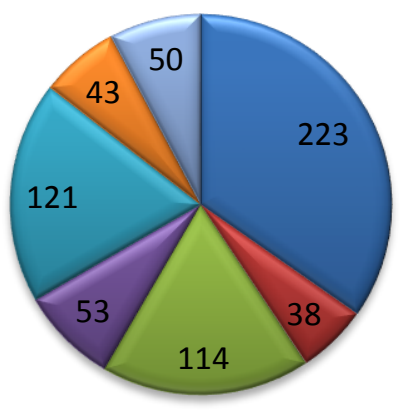

a Muko-muko (St.1)

DTalao Tubo (St.2)

口Muaro Talao (St.3)

- Muaro Tanjung (St.4)

- Bayur (St.5)

$\square$ Muaro Pisang (St.6)

Gandan (St.7)

Melanoides tuberculata

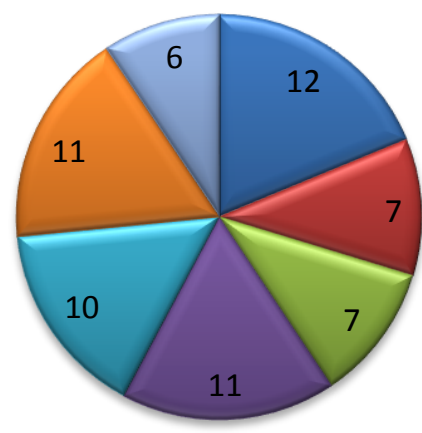

口 Muko-muko (St.1)

- Talao Tubo (St.2)

$\square$ Muaro Talao (St.3)

Muaro Tanjung (St.4)

$\square$ Bayur (St.5)

$\square$ Muaro Pisang (St.6)

$\square$ Pandan (St.7)

Anodonta Woodiana

Gambar 2. Jumlah rata-rata moluska di muara sungai sekitar Danau Maninjau

Penelitian ini dilakukan terhadap moluska yang menjadi konsumsi masyarakat sekitar, yaitu pensi (Corbicula moltkiana); langkitang (Melanoides tuberculata) dan lokan (Anodonta woodiana). Spesiesspesies moluska tersebut telah dimanfaatkan sebagai salah satu komoditas perikanan oleh masyarakat seputar D.
Maninjau. Kegiatan penangkapan pensi dan langkitang merupakan salah satu aktivitas perikanan nelayan di D. Maninjau yang relatif kecil, dibanding penangkapan ikan dan budidaya dengan KJA. Spesies $C$. moltkiana sendiri memiliki sebaran dari Sumatera hingga Semenanjung Malaysia yang diantaranya ditemukan di D. Maninjau (Djajasasmita, 1999). Penangkapan pensi yang berlangsung sepanjang waktu dan ancaman dari aktivitas manusia lainnya dapat memberikan dampak buruk bagi populasi pensi. Pada saat ini penangkapan pensi cenderung eksploitatif, tidak ada aturan dan pembatasan baik jumlah hasil tangkapan, ukuran alat maupun waktu tangkap. Pensi menjadi komoditas perikanan, selain untuk konsumsi masyarakat setempat juga menjadi "oleh-oleh" D. Maninjau sebagai potensi wisata kuliner (Lukman, 2015).

Hampir seluruh tepian D. Maninjau hingga kedalaman tiga meter merupakan lokasi penangkapan pensi dan langkitang. Terdapat pusat-pusat penangkapan pensi yang biasanya berhubungan dengan kondisi fisik tepian danau yaitu pada tepian landai dan kedekatan dengan tempat tinggal nelayan. Pola sebaran aktivitas penangkapan pensi umumnya terdapat di bagian utara dari D. Maninjau. Hewan air jenis kerang-kerangan (bivalva) atau jenis hewan lunak (moluska), baik jenis kerang besar (klam) atau kerang kecil (oyster), pergerakannya sangat lambat di dalam air dan biasanya hidup menetap di suatu lokasi tertentu di dasar air.

\section{Pola Penyebaran Moluska}

Pola penyebaran biota dipengaruhi oleh tipe habitat yang meliputi nilai konsentrasi fisika dan kimia perairan, makanan serta kemampuan beradaptasi terhadap perubahan lingkungan yang terjadi. Berdasarkan hasil pengamatan pola penyebaran jenis moluska pensi (Corbicula moltkiana) dan langkitang (Melanoides tuberculata) menunjukkan kecenderungan hidup berkelompok. Sifat berkelompok ini disebabkan oleh beberapa faktor antara lain kondisi lingkungan, tipe substrat, kebiasaan makan dan cara bereproduksi (Lukman, 2015). Cara hidup biota yang berkelompok menunjukkan kecenderungan yang kuat untuk berkompetisi dengan biota yang lain terutama dalam hal makan. Kebiasaan makan dan sumber makanan bagi moluska berbeda-beda untuk setiap jenis dan dipengaruhi oleh pola adaptasi terhadap lingkungannnya. Sumber makanan bagi hewan yang hidup di dasar perairan (bentos) terdiri dari detritus dan plankton dari massa air serta detritus dan mikroorganisme yang melekat di dasar. Pada umumnya moluska yang bersifat pemakan deposit lebih banyak ditemukan di daerah dengan substrat yang halus karena banyak mengandung bahan organik. Walaupun moluska pemakan suspensi dapat ditemukan pada substrat yang kasar, namun dapat juga ditemukan moluska pemakan deposit. Sedangkan pada bivalvia, 
sebagian besar pemakan detritus dan sebagian kecil adalah pemakan plankton (Hamli et al., 2015).

Berdasarkan data di Tabel 1 menunjukkan jumlah langkitang terbanyak terdapat pada stasiun MukoMuko dan jumlahnya berbeda nyata dengan stasiunstasiun lain. Jumlah moluska pensi terbanyak terdapat pada stasiun Pandan, Bayur, Muaro Pisang, dan Muaro Tanjung dimana jumlah moluska pensi pada keempat stasiun tersebut berbeda nyata dengan stasiun-stasiun lain. Jumlah moluska lokan tidak berbeda nyata antar masingmasing stasiun.

Tabel 1. Hasil Anova dan Uji Duncan pada jumlah moluska di muara sungai

\begin{tabular}{lccc}
\hline \hline \multirow{2}{*}{ Stasiun } & \multicolumn{3}{c}{ Moluska } \\
\cline { 2 - 4 } & Pensi & Langkitang & Lokan \\
\hline Muko- & $294.6^{\mathrm{c}} \pm$ & $44.6^{\mathrm{a}} \pm$ & $2.4^{\mathrm{a}} \pm$ \\
Muko & 94.13 & 17.27 & 1.14 \\
Talao Tubo & $365.4 \mathrm{~b}^{\mathrm{c}} \pm$ & $7.6^{\mathrm{c}} \pm 2.41$ & $1.4^{\mathrm{a}} \pm$ \\
Muaro & 93.29 & $22.8^{\mathrm{b}} \pm$ & $1.4^{\mathrm{a}} \pm$ \\
Talao & $297.4^{\mathrm{c}} \pm$ & 18.27 & 0.55 \\
Muaro & 137.58 & $10.6^{\mathrm{c}} \pm 3.28$ & $2.2^{\mathrm{a}} \pm$ \\
Tanjung & $567.2^{\mathrm{ab}} \pm$ & 0.84 \\
Bayur & 136.06 & $486.2^{\mathrm{ab}} \pm$ & $2^{\mathrm{a}} \pm 0.71$ \\
Muaro & $24.2^{\mathrm{b}} \pm 9.73$ & 177.74 & $2.2^{\mathrm{a}} \pm$ \\
Pisang & $509.4^{\mathrm{ab}} \pm$ & $8.6^{\mathrm{c}} \pm 3.05$ & 1.09 \\
Pandan & 92.27 & & $1.2^{\mathrm{a}} \pm$ \\
& $635^{\mathrm{a}} \pm$ & $10.6^{\mathrm{c}} \pm 3.28$ & 0.45 \\
\hline Ket: & 234.69 & &
\end{tabular}

Ket: Mean \pm stdev $(\mathrm{a}, \mathrm{b}$, dan c) yang memiliki huruf berbeda pada satu kolom menunjukan perbedaan yang signifikan pada taraf $5 \%$.

\section{Tipe Substrat}

Berdasarkan hasil penelitian menunjukkan bahwa muara sungai-sungai di sekitar D. Maninjau secara umum memiliki tipe substrat berpasir, lempung berliat dan liat. Gambar 3 menunjukan bahwa muara sungai di sekitar D. Maninjau didominasi oleh substrat pasir, khususnya pada St. 1 (Muko-muko). Tingginya fraksi sedimen hampir di semua stasiun khususnya di stasiun 1 berkaitan dengan lokasi yang berada di muara yang masih terpengaruh oleh arus dan gelombang. Fraksi sedimen pasir lebih lama terendapkan daripada fraksi yang lebih halus. Akibatnya partikel-partikel tersuspensi ini akan terbawa dan terendapkan di muara sungai. Dengan karakteristik substrat di tepian D. Maninjau yang beragam (Gambar 3) menentukan pula potensi sumberdaya pensi di perairan tersebut.

Tipe sedimen berupa pasir yang terbentang di sisi utara dan timur D. Maninjau merupakan habitat penting pensi. Sementara itu beberapa wilayah tepian Danau Maninjau, ternyata tidak dapat dimanfaatkan sebagai lokasi penangkapan terutama karena kondisi tepian yang cukup curam. Tipe substrat pasir memberikan habitat dengan kelimpahan pensi tertinggi, disusul substrat campuran pasir dan lumpur, dan kelimpahan terendah pada habitat dengan substrat kerikil dan batuan.
ST 1

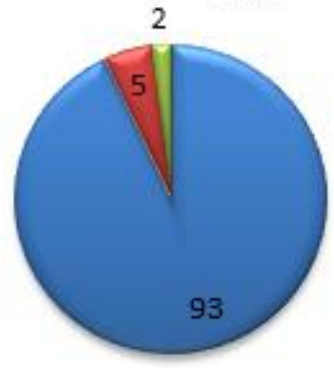

ST 3

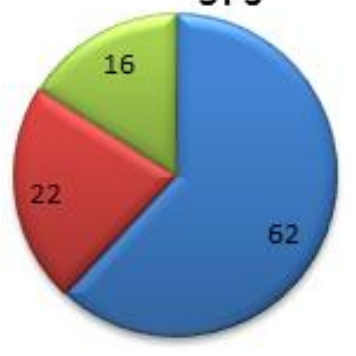

ST 5

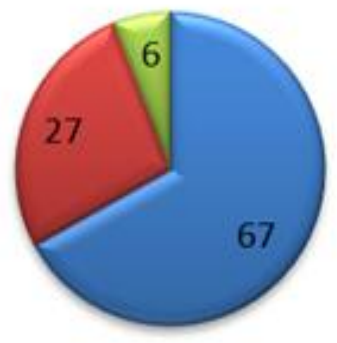

ST 7

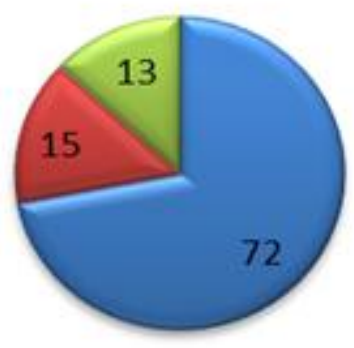

ST 2

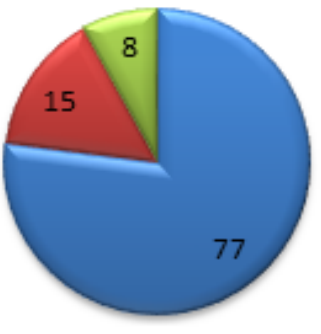

ST 4

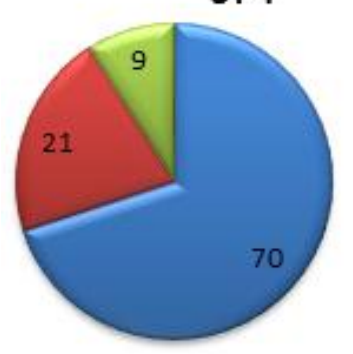

ST 6

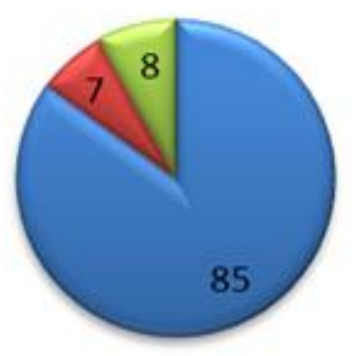

Keterangan warna:

Pasir (\%)

Debu (\%)

$\square$ Liat $(\%)$
Gambar 3. Persentasi rata-rata fraksi sedimen di muara sungai

Keterangan : St. 1 Muko-Muko; St. 2 Talao Tubo; St. 3 Muaro Talao; St. 4 Muaro Tanjung; St. 5 Bayur; St. 6 Muaro Pisang; St. 7 Pandan 
Kondisi tersebut sejalan dengan Dernie et al. (2003) bahwa secara umum pada suatu proses pemulihan habitat bentik dari komunitas infauna di wilayah pesisir, gangguan fisik di habitat berpasir lebih cepat pulih dibanding pada habitat endapan sedimen berlumpur. Hal ini mengindikasikan bahwa habitat berpasir memberikan dukungan perkembangan populasi biota bentik dan juga pensi lebih baik dibanding habitat lainnya (Lukman, 2015).

\section{Distribusi Konsentrasi Total Nitrogen (TN) dan Total Fosfat (TP) di Sedimen}

Konsentrasi TN dan TP pada sedimen tersebar merata di setiap stasiun dengan nilai konsentrasi TN berkisar 0,093 - 0,610 $\mathrm{mg} \mathrm{kg}^{-1}$. Konsentrasi tertinggi terdapat di St. 2 (Talao Tubo) dan terendah pada St. 5 (Bayur). Konsentrasi untuk TP berkisar 0,427 - 2,137 mg $\mathrm{kg}^{-1}$. Konsentrasi tertinggi terdapat di St. 4 (Muaro Tanjung) dan terendah pada St. 5 (Bayur) (Gambar 4). Pada sedimen di muara sungai yang masuk ke D. Maninjau terlihat konsentrasi TP lebih tinggi dibandingkan TN. Hal ini diduga tingginya masukan dari antropogenik yang berasal dari daerah pertanian ataupun perkebunan. Fairchild et al., (1987) menyebutkan pengaruh dari drainase pertanian umumnya akan meningkatkan konsentrasi partikel sedimen tersuspensi dan nilai konduktivitas di perairan. Daerah sekitar D. Maninjau terkenal dengan daerah pertanian dan perkebunan yang cukup subur seperti padi, cabai, bawang serta sayur-sayuran yang menjadi salah satu komoditi daerah setempat. Keberadaan fosfat di perairan adalah sangat penting terutama berfungsi dalam pembentukan protein dan metabolisme bagi organisme. Fosfat dalam perairan tawar ataupun air limbah pada umumnya dalam bentuk fosfat, yaitu ortofosfat, fosfat terkondensasi seperti pirofosfat $\left(\mathrm{P}_{2} \mathrm{O}_{7}{ }^{4-}\right)$, metafosfat $\left(\mathrm{P}_{3} \mathrm{O}_{9}{ }^{3-}\right)$ dan polifosfat $\left(\mathrm{P}_{4} \mathrm{O}_{13}{ }^{6-}\right.$ dan $\left.\mathrm{P}_{3} \mathrm{O}_{10}{ }^{5-}\right)$ serta fosfat yang terikat secara organik (adenosin monofosfat) (Lenat, 1984).

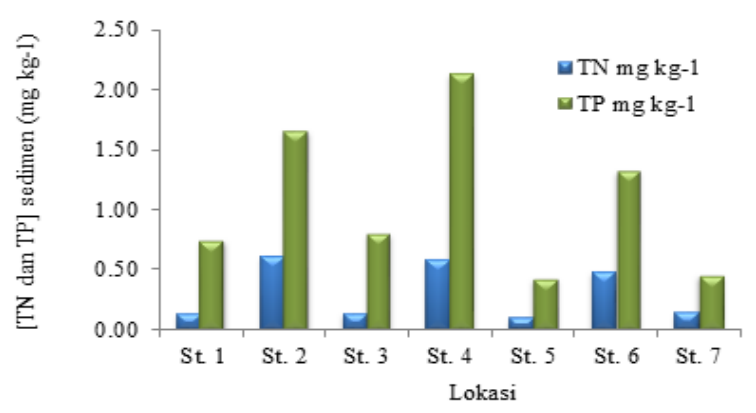

Gambar 4. Konsentrasi total nitrogen dan total fosfat di sedimen muara sungai

Keterangan: St 1 = Muko-Muko, St 2 = Talao Tubo, St 3 = Muaro Talao, St 4 Muaro Tanjung, St $5=$ Bayur, St 6 Muaro Pisang, St $7=$ Pandan
Kandungan nutrien dalam pupuk menyebabkan proses eutrofikasi pada air permukaan, akumulasi nitrat dalam air tanah, pengasaman tanah, dan $\mathrm{N}_{2} \mathrm{O}$ (gas yang juga menyebabkan efek rumah kaca). Air lindi yang mengandung nitrat yang mencemari air tanah dan air permukaan juga mengancam ketersediaan sumber air minum. Nitrogen dan fosfat yang terbawa menuju air permukaan menyebabkan eutrofikasi pada danau, sungai, dan perairan dangkal. Senyawaan ini berada sebagai larutan, partikel atau detritus atau berada di dalam tubuh organisme akuatik (Faust \& Osman, 198). Menurut Perkins (1974), kandungan fosfat yang terdapat di perairan umumnya tidak lebih dari $0,1 \mathrm{mg} \mathrm{\textrm {L } ^ { - 1 }}$, kecuali pada perairan yang menerima limbah dari rumah tangga dan industri tertentu, serta dari daerah pertanian yang mendapat pemupukan fosfat. Oleh karena itu, perairan yang mengandung kadar fosfat yang cukup tinggi melebihi kebutuhan normal organisme akuatik akan menyebabkan terjadinya eutrofikasi.

\section{Kesimpulan}

Moluska jenis pensi (Corbicula moltkiana) paling banyak ditemukan di stasiun Pandan, sedangkan langkitang (Melanoides tuberculata) dan lokan (Anodonta woodiana) paling banyak ditemukan di stasiun Muko-Muko. Pola sebaran jenis moluska pensi (Corbicula moltkiana) dan langkitang (Melanoides tuberculata) menunjukkan kecenderungan hidup berkelompok. Perairan muara sungai di sekitar Danau Maninjau didominasi oleh substrat berupa pasir dengan konsentrasi TN dan TP substrat masing-masing berkisar 0,093-0,610 $\mathrm{mg} \mathrm{kg}^{-1}$ dan 0,427-2,137 $\mathrm{mg} \mathrm{kg}^{-1}$.

\section{Ucapan Terima Kasih}

Terima kasih kami sampaikan kepada Bapak Aiman Ibrahim dari Puslit Limnologi-LIPI yang telah banyak membantu dan memberi masukan dalam penulisan ini.

\section{Referensi}

[APHA] American Public Health Association (2012). Standard Method for The Examination of Water and Wastewater 22 ${ }^{\text {th }}$ ed., AWWA (American Water Works Association), and WEF (Water Environment Federation). Washington D.C. 20001-3710.

Arbi, UY. (2016). Moluska Benthik di Perairan Lima Muara Sungai Kawasan Teluk Lamong, Surabaya, Jawa Timur. Journal of Tropical Biodiversity and Biotechnology, $\quad 1 \quad$ (2): $\quad 55--61$. https://jurnal.ugm.ac.id/jtbb/article/view/13736/1 $\underline{6374}$. 
Brusca RC, \& Brusca GJ. (1990). Invertebrates. Massachusetts: Sinauer. ISBN-13: 9780878930975 ISBN-10: 0878930973

Dernie KM, Kaiser MJ, Richardson EA, \& Warwick RM. (2003). Recovery of soft sediment communities and habitats following physical disturbance. $J$. of Exp. Mar. Biol. and Ecol. 285/286: 415 - 434. DOI: 10.1016/S0022-0981(02)00541-5

Djajasasmita M. (1999). Keong dan Kerang Sawah. Puslitbang Biologi-LIPI.

Fairchild JL, Boyle T, English WR, \& Rabeni C. (1987). Effects of Sediment and Contamination Sediment on Structural and Component of Experimental Stream Ecosystems, Water air, and Soil Pollution 36:271-293. https://doi.org/10.1007/BF00229673

Faust SD \& Osman MA. (1981). Chemistry of Natural Water. Ann Arbor Science Publisher Inc. Michigan.

Hamidah, A. (2015). Jenis dan Kepadatan Moluska di Danau Kerinci Provinsi Jambi. Prosiding Semirata 2015 bidang MIPA BKS-PTN Barat Universitas Tanjungpura Pontianak hal 65-73. https://jurnal.untan.ac.id/index.php/semirata2015/ article/view/13667.

Hamli H, Idris MH, Rajaee AH, \& Kamal AHM. (2015). Reproductive cycle of hard clam, Meretrix lyrata Sowerby, 1851 (Bivalvia: Veneridae) from Sarawak, Malaysia. Early View. Tropical Life Sciences Research. University Sains Malaysia Press.

https://www.ncbi.nlm.nih.gov/pmc/articles/PMC4 $\underline{729408}$

Henanusa, PE \& Haryani, GS. (2009). Klasifikasi morfogenesis danau di Indonesia untuk mitigasi dampak perubahan iklim. Makalah disampaikan dalam Konferensi Nasional Danau Indonesia I, Sanur-Denpasar-Bali, 13--15 Agustus 2009.

Kumurur VA. (2002). Aspek strategis pengelolaan Danau Tondano secara terpadu. Ekoton 2 (1): 73-80. https://ejournal.unsrat.ac.id/index.php/EKOTON/ article/view/266/212

Mardatila, S., Izmiarti, \& Nurdin, J. (2016). Kepadatan, Keanekaragaman dan Pola Distribusi Gastropoda di Danau Diatas, Kabupaten Solok, Provinsi Sumatera Barat. Jurnal Biocelebes, 10 (2).
http://jurnal.untad.ac.id/jurnal/index.php/Bioceleb es/article/view/7379.

Marwoto, RM. \& Djajasasmita, M. (1986). Fauna Moluska di Perairan Tepi Danau Singkarak Sumatera Barat: Komposisi dan Kepadatan Jenisnya. Berita Biologi 3(6).https://ejournal.biologi.lipi.go.id/index.php/ berita_biologi/article/view/1329.

Lenat DR. (1984). Agriculture and Stream Water Quality: A Biological Evaluation of Erosion Control Practices. Environmental Management vol. 8 (4): 334-344.

https://link.springer.com/article/10.1007/BF01868 $\underline{032}$

Lukman (2015). Populasi Pensi (Corbicula moltkiana, Prime 1878) di Danau Maninjau Terkait Penangkapannya dan Aktivitas Karamba Jaring Apung. [Disertasi] Pasca Sarjana, FPIK-IPB.

Manganaro A, Pulicano G, Reale A, Sanfilippo M, \& Sara G. (2009). Filtration pressure by bivalves affect the trophic conditions in Mediterranean shallow ecosystems. Chemistry \& Ecology 25(6): 1 -12.https://doi.org/10.1080/02757540903325120

Payne AL. (1986). The Ecology of Tropical Lakes and Rivers. John Wiley and Sons. Singapore. https://doi.org/10.1002/iroh.19930780115

Perkins EJ. (1974). The Biology of Estuaries and Coastal Water. Academic Press Co. New York. https://doi.org/10.4319/1o.1975.20.4.0684

Sousa R, Antunes C, \& Guilhermino L. (2007). Species composition and monthly variation of the molluscan fauna in the freshwater subtidal area of the River Minho Estuary. Estuarine, Coastal and Shelf Science 75: $90 \quad-100$ DOI: 10.1016/j.ecss.2007.02.020

Shalihah, HN, Purnomo, PW, \& Widyorini (2017). Keanekaragaman Moluska Berdasarkan Tekstur Sedimen dan Kadar Bahan Organik Pada Muara Sungai Betahwalang,Kabupaten Demak. Saintek Perikanan, $\quad 13 \quad$ (1): $\quad$ 58-64. https://ejournal.undip.ac.id/index.php/saintek.

Surbakti, S. (2011). Biologi dan Ekologi Thiaridae (Moluska: Gastropoda) di Danau Sentani Papua. Jurnal Biologi Papua, 3 (2): 59-66. rnal.uncen.ac.id/index.php/JBP/article/view/550. 
Syawal, MS. et al. (2020). Jurnal Biologi Tropis, 20 (3): 492 - 498 DOI: http://dx.doi.org/10.29303/jbt.v20i3.2263

Tanjung, L. R. (2015). Moluska Danau Maninjau: Kandungan nutrisi dan potensi ekonomisnya. LIMNOTEK-Perairan Darat Tropis di Indonesia, 22(2). https://limnotek.limnologi.lipi.go.id/index.php/li $\underline{\text { mnotek/article/view/37 }}$

Zettler, M. L., \& Daunys, D. (2007). Long-term macrozoobenthos changes in a shallow boreal lagoon: comparison of a recent biodiversity inventory with historical data. Limnologica, 37(2), 170-185.

https://www.sciencedirect.com/science/article/pii/ $\underline{\mathrm{S} 0075951107000072}$ 